OPEN ACCESS

Edited by:

Jean-François Desaphy, University of Bari Aldo Moro, Italy

Reviewed by: Ildikò Szabò,

University of Padova, Italy Paola Imbrici, University of Bari Aldo Moro, Italy

*Correspondence: Elena Lastraioli elena.lastraioli@unifi.it

Specialty section: This article was submitted to Pharmacology of Ion Channels and Channelopathies, a section of the journal Frontiers in Pharmacology

Received: 13 January 2020 Accepted: 01 May 2020 Published: 20 May 2020

Citation: Lastraioli E (2020) Focus on TripleNegative Breast Cancer: Potassium Channel Expression and Clinical Correlates. Front. Pharmacol. 11:725. doi: 10.3389/fphar.2020.00725

\section{Focus on Triple-Negative Breast Cancer: Potassium Channel Expression and Clinical Correlates}

\author{
Elena Lastraioli * \\ Department of Experimental and Clinical Medicine, University of Florence, Florence, Italy
}

Despite improvements in early diagnosis and treatment, breast cancer is still a major health problem worldwide. Among breast cancer subtypes, the most challenging and harder to treat is represented by triple-negative molecular subtype. Due to its intrinsic features this subtype cannot be treated neither with hormonal therapy (since it does not express estrogen or progesterone receptors) nor with epidermal growth factor receptor 2 (HER2) inhibitors (as it does not express high levels of this protein). For these reasons, the standard of care for these patients is represented by a combination of surgery, radiation therapy and chemotherapy. In this scenario, searching for novel biomarkers that might help both in diagnosis and therapy is mandatory. In the last years, it was shown that different families of potassium channels are overexpressed in primary breast cancers. The altered ion channel expression may be useful for diagnostic and therapeutic purposes due to some peculiar characteristics of this class of molecules. Ion channels are defined as pore-forming transmembrane proteins regulating passive ion fluxes in the cells. Ion channels represent good potential markers since, being localized at the plasma membrane level, their detection and block with specific drugs and antibodies might be fast and tunable. This review focuses on triple-negative breast cancers and recapitulates the current knowledge about potassium channels' clinical relevance and their potential use in the clinical setting, for triple-negative breast cancer diagnosis and therapy.

Keywords: potassium channels, breast cancer, triple-negative breast cancer, treatment, prognosis

\section{INTRODUCTION}

Breast cancer $(\mathrm{BC})$ is a heterogeneous disease composed of different molecular subtypes, with peculiar histopathological and biomolecular features. Currently BC classification relies on the detection of four biomarkers: estrogen receptor (ER), progesterone receptors (PgR), human epidermal growth factor receptor 2 (HER2), and the proliferation index (Ki67 staining). Applying such molecular classification, five main BC subtypes with different features and prognosis can be defined: Luminal A, Luminal B, HER2-positive, triple-negative (TNB), and normal-like. Among $\mathrm{BC}$ subtypes, the most challenging and harder to treat is represented by triplenegative BC (TNBC) (Santana-Davila and Perez, 2010; Penault-Llorca and Viale, 2012).

In this scenario, searching for novel biomarkers that might help clinicians in $\mathrm{BC}$ management appears to be mandatory. Mounting evidences gathered in the last 20 years pointed out that several 
ion channels might represent biomarkers, since their expression is frequently dysregulated in BC and association with clinicopathological features have been described for some of them.

The aim of the present review is to summarize the current knowledge about potassium channels relevance in BC with a special focus on their role in treatment and patients' outcome.

\section{CLINICAL FEATURES OF TNBC}

According to data recently published by the American Cancer Society (American Cancer Society, 2017), TNBC accounts for $12 \%$ of all BC. Its incidence is higher in young patients, in subjects carriers of BRCA1 mutations (Perou and Børresen-Dale, 2011) and of particular ethnicity (African American and Hispanic women are at higher risk with respect to Caucasians) (Millikan et al., 2008). TNBC patients generally have a bad prognosis since their tumors are often bigger, classified as G3 and with lymphnode involvement (Dent et al., 2007). The main features of TNBCs are summarized in Table $\mathbf{1}$.

\section{HISTOPATHOLOGY OF TNBC}

From a histopathological point of view, most TNBC are classified as invasive ductal carcinomas of no special type (Carey et al., 2006) that could display basal-like features or not. A minor part of TNBC belongs to rare histological types such as atypical or typical medullary-like (Jacquemier et al., 2005; Livasy et al., 2006), apocrine carcinomas and pleomorphic lobular carcinomas (Kreike et al., 2007), metaplastic carcinomas (Livasy et al., 2006; Reis-Filho et al., 2006), and adenoid cystic carcinomas (Cleator et al., 2007). Among them, it was shown that metaplastic and medullary-like cancers display basal-like features that are uncommon in the other histotypes (Jacquemier et al., 2005; Bertucci et al., 2006; Rodriguez-Pinilla et al., 2007). Three representative pictures of TNBC of different histotype are reported in Figure 1.

As summarized in Table 1, TNBC are frequently associated with aggressive histopathological characteristics such as an abundant lymphocytic infiltrate and central necrotic area, high grading (either nuclear and histological), high mitotic rate, presence of pushing margins and altered nuclear-cytoplasmatic ratio (Tot, 2000; Fulford et al., 2006; Livasy et al., 2006; Bauer et al., 2007; Kreike et al., 2007; Millikan et al., 2008; Sasa et al., 2008; Kaplan et al., 2009).

\section{BIOMOLECULAR FEATURES OF TNBC}

Since the terms "TNBC" and "Basal-like" are not synonymous, although they share many common features, a thorough analysis of a great cohort of samples in the METABRIC study according to PAM50 (Curtis et al., 2012; Engebraaten et al., 2013) was performed: such analysis showed that most TNBC are classified
TABLE 1 | Triple-negative breast cancer (TNBC) characteristics.

\begin{tabular}{|c|c|c|c|}
\hline \multicolumn{2}{|c|}{ CHARACTERISTIC } & TNBC & Basal-like BC \\
\hline \multicolumn{2}{|l|}{ Age of Onset } & $<50$ years & $<50$ years \\
\hline \multicolumn{2}{|l|}{ Ethnicity } & $\begin{array}{l}\text { More frequent in } \\
\text { African American }\end{array}$ & $\begin{array}{l}\text { More frequent in } \\
\text { African American }\end{array}$ \\
\hline \multicolumn{2}{|c|}{ Radiological findings } & $\begin{array}{l}\text { Hyperdense masses; } \\
\text { no calcifications }\end{array}$ & $\begin{array}{l}\text { Hyperdense masses; } \\
\text { no calcifications }\end{array}$ \\
\hline \multirow{5}{*}{$\begin{array}{l}\text { Histological } \\
\text { features }\end{array}$} & Grading & G2-G3 & G3 \\
\hline & Invasive & Yes & Yes \\
\hline & $\begin{array}{l}\text { Subtype } \\
\text { Growing }\end{array}$ & $\begin{array}{l}\text { Ductal carcinomas of } \\
\text { no special type }\end{array}$ & $\begin{array}{l}\text { Ductal carcinomas of } \\
\text { no special type, with }\end{array}$ \\
\hline & pattern & Pushing borders & Basal-like features \\
\hline & $\begin{array}{l}\text { Lymphocytic } \\
\text { infiltrate }\end{array}$ & High & $\begin{array}{l}\text { Pushing borders } \\
\text { High }\end{array}$ \\
\hline \multirow{7}{*}{$\begin{array}{l}\text { Molecular } \\
\text { features }\end{array}$} & ER & - & - \\
\hline & $\mathrm{PgR}$ & - & - \\
\hline & HER2 & - & - \\
\hline & CK5 & + & ++ \\
\hline & CK17 & + & ++ \\
\hline & EGFR & + & + \\
\hline & Cyclin E & + & + \\
\hline \multirow[t]{2}{*}{ Prognosis } & After 5 years & intermediate & unfavorable \\
\hline & $\begin{array}{l}\text { Relapse (10 } \\
\text { years) }\end{array}$ & Rare & Very rare \\
\hline \multirow[t]{4}{*}{ Therapy } & Chemotherapy & $\begin{array}{l}\text { Yes (especially } \\
\text { combinations with }\end{array}$ & Yes \\
\hline & Trastuzumab & $\begin{array}{l}\text { Doxorubicin and } \\
\text { taxanes) }\end{array}$ & No \\
\hline & $\begin{array}{l}\text { Hormonal } \\
\text { therapy }\end{array}$ & No & No \\
\hline & & No & \\
\hline
\end{tabular}

ER, estrogen receptor; PgR, progesterone receptor; CK, cytokeratin; EGFR, epidermal growth factor receptor; -, negative by definition; -, almost always negative; -, usually negative; +, usually positive; ++, almost always positive.

as Basal-like (86.1\%) but also other subtypes such as HER2enriched, normal-like and Luminal A are represented.

The gene expression analysis of the same cohort showed that the higher percentage of basal-like tumors do not express ER, PgR and HER2 (and are therefore defined as triple negative), but there are also samples expressing either ER or HER2. Due to the discrepancy between the two classifications, several efforts have been made to provide a more precise classification using immunohistochemical markers such as cytokeratin and EGFR (see also Table 1) (Nielsen et al., 2004; Carey et al., 2006; Blows et al., 2010; Broeks et al., 2011).

\section{TNBC TREATMENT}

As stated before, TNBC represent the most difficult to treat due to the absence of good targets such as hormone receptors or other molecules to be specifically targeted with effective drugs. A recent review (Yu et al., 2020) described some novel potential targets such as gene targets, Noncoding RNA, classical signaling pathways among others. From a clinical point of view, in 2017 the Food and Drug Administration (FDA) approved the use of cyclin-dependent kinases 4/6 (CDK4/6) inhibitors (ribociclib, 

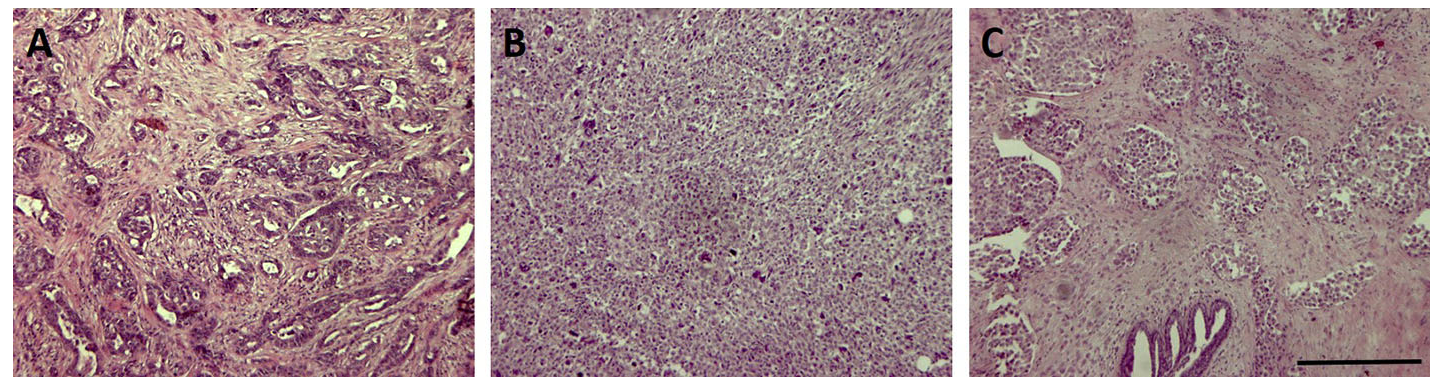

FIGURE 1 | Representative pictures of three triple-negative breast cancer (TNBC) samples of different histotype stained with Hematoxylin \& Eosin. Bar: 100um. (A) invasive ductal carcinoma; (B) invasive metaplastic carcinoma-spindle cell subtype; (C) invasive lobular carcinoma.

palbociclib, abemaciclib) for ER+ and HER2- advanced BC (Eggersmann et al., 2019). In the following year, also PARP inhibitors (talazoparib, olaparib) were approved for HER2- and BRCA1/2-mutant advanced BC (McCann and Hurvitz, 2018).

\section{POTASSIUM CHANNELS}

Ion channels have been proven to be expressed in human tumors of different origin and it was shown that they act in different manners, modulating several key cell processes. For these reasons, ion channels could represent novel cancer biomarkers, once properly validated in the clinical setting. Being localized in the plasma membrane, ion channel detection might be easily performed by IHC and molecular techniques thus raising the possibility of quick detection of the protein; moreover, for the same reason, they represent a good potential target for therapy with specific drugs and antibodies.
Potassium channels are a multi-gene family composed of several subfamilies (Figure 2): voltage-gated potassium channels, inward rectifiers, two-pore domains and calcium-activated channels (reviewed in D'Amico et al., 2013). In Voltage-gated potassium channels four subunits surround an aqueous pore: each subunit is composed by six transmembrane domains (S1S6), of which S4 represents the voltage sensor while the pore (P) is defined by a loop between S5 and S6. The channels belonging to the Inward rectifiers subfamily are composed of four subunits, each with two transmembrane domains linked by a P-loop. Channels classified as Two-pore domains are characterized by four transmembrane domains and an aqueous pore formed by two regions. Another subfamily is represented by Calciumactivated potassium channels: these channels belong to two groups of proteins named "small- and intermediateconductance" (SK) and "high-conductance" potassium channels (BK). The former are tetramers composed by six transmembrane domains (S1-S6) each with the central pore
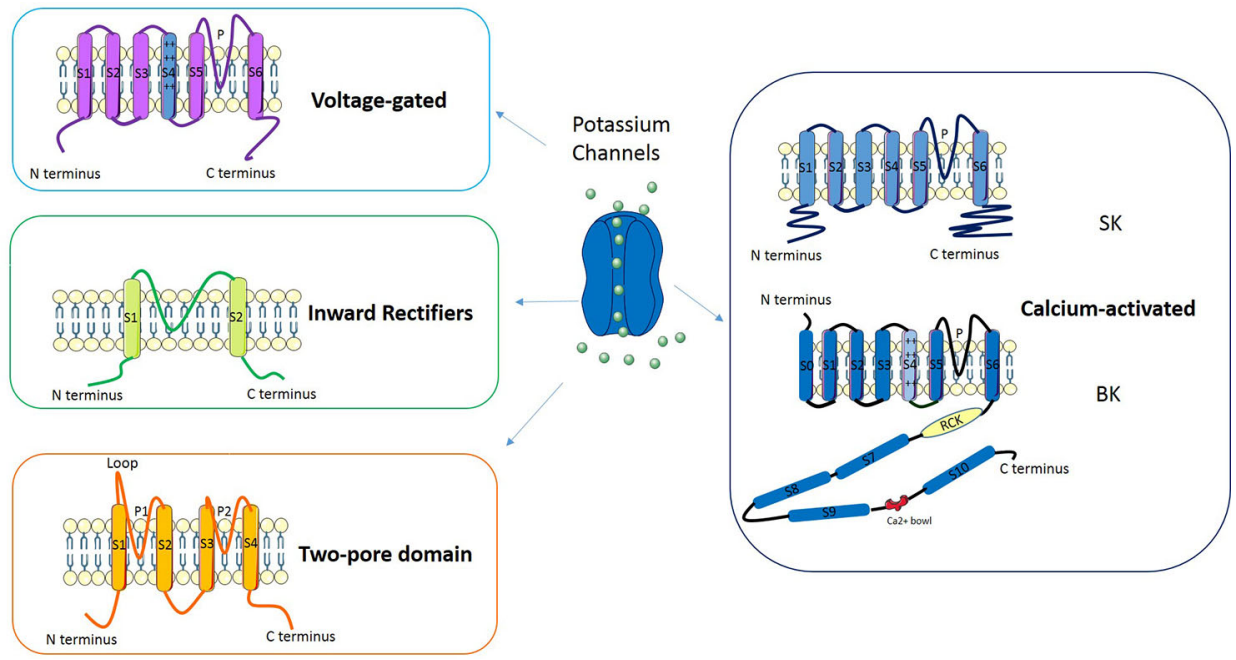

FIGURE 2 | Classification and molecular structure of potassium channels. 
located in the S5-S6 region; the latter are tetramers made of $\alpha$ and $\beta$ subunits in which the pore is formed by $\alpha$ subunits.

\section{POTASSIUM CHANNELS IN BC}

It is well known that that ion channels are aberrantly expressed in different tumors (see, for example, the review by Lastraioli et al., 2015a). Among them, potassium channels have been shown to be overexpressed in primary BCs and cell lines (reviewed in Lastraioli, 2018). In Table 2, a detailed list of the potassium channels whose expression has been described in $\mathrm{BC}$ are reported.

Kv1.3 channels, are members of the voltage-gated family, encoded by KCNA3 gene. It has been shown that Kv1.3 channels have a key role in several cell processes such cell proliferation, apoptosis, setting the cell resting membrane potential and regulating cell volume (Cahalan and Chandy, 2009; Teisseyre et al., 2015). Kv1.3 channels have been shown to be associated with poor prognosis in BC patients (Jang et al., 2009). The expression of Kv1.3 mRNA and the corresponding protein was proven to be reduced in grade III BC and an inverse association with tumor grade and advanced stage (Brevet et al., 2009) emerged. The same Authors, demonstrated that the methylation of the promoter of the gene increased in grade III tumors (thus decreasing KCNA3 transcription) and it is associated with poor differentiation and younger age of the patients (Brevet et al., 2009). Recently, the potential use of Kv1.3 for cancer diagnostic and therapy has been reviewed (Teisseyre et al., 2019).
Kv10.1 (Eag1 or KCNH1) is a voltage-gated potassium channel encoded by the KCNH1 gene. In physiological conditions, Kv10.1 channels are expressed mainly in brain, adrenal gland, myoblasts, placenta and testis (Bijlenga et al., 1998; Ouadid-Ahidouch et al., 2016). In excitable tissues (muscle and brain) Kv10.1 channel sustains hyperpolarization and controls neuronal excitability (Ouadid-Ahidouch et al., 2016). Nevertheless, Kv10.1 expression has been described also in several human tumors at difference from the corresponding normal tissues both at the mRNA and protein level (Hemmerlein et al., 2006). High Kv10.1 protein levels have been found in human BCs (Hemmerlein et al., 2006; García-Becerra et al., 2010) and it was shown that Kv10.1 expression is higher in invasive-ductal carcinomas than in fibroadenomas (GarcíaBecerra et al., 2010). More interestingly, Kv10.1 is highly expressed in TNBCs with respect to other molecular subtypes and it was shown that it is associated with tumor stage, size, and lymph node involvement (Liu et al., 2015). In BC cell lines it was shown that the combination of Astemizole (Kv10.1 blocker) and gefitinib (EGFR inhibitor) have a synergic effect in impairing proliferation in BC cells expressing both proteins (García-Quiroz et al., 2019a). The same Author also showed that the combined treatment with calcitriol and curcumin or resveratrol had a synergistic effect both in vitro and in vivo in human mammary tumor cells (García-Quiroz et al., 2019b).

Kv11.1 (also named hERG1) encoded by KCNH2 gene, is another member of the voltage-gated family that has been shown to be overexpressed in several solid tumors (Lastraioli

TABLE 2 | Potassium channels expressed in primary breast cancer (BC).

\begin{tabular}{|c|c|c|c|c|c|}
\hline FAMILY & $\begin{array}{l}\text { HGNC } \\
\text { name }\end{array}$ & $\begin{array}{l}\text { IUPHAR } \\
\text { name }\end{array}$ & $\begin{array}{l}\text { Alternative } \\
\text { names }\end{array}$ & GENE & Clinical correlations \\
\hline \multirow[t]{3}{*}{ Voltage-gated } & KCNA3 & $\mathrm{Kv1.3}$ & $\begin{array}{l}\text { MK3, HLK3, } \\
\text { HPCN3 }\end{array}$ & KCNA3 & Poor prognosis (Brevet et al., 2009), advanced stage, younger age (Jang et al., 2009) \\
\hline & $\mathrm{KCNH} 1$ & $K_{v} 10.1$ & eag1 & $\mathrm{KCNH1}$ & $\begin{array}{l}\text { Overexpression (Hemmerlein et al., 2006), correlation with vitamin D receptor in invasive } \\
\text { ductal carcinomas (García-Becerra et al., 2010), poor prognosis' high expression in TNBC, } \\
\text { association with stage, positive lymph nodes, higher expression in invasive ductal carcinomas } \\
\text { (Liu et al., 2015) }\end{array}$ \\
\hline & $\mathrm{KCNH} 2$ & $\mathrm{~K}_{\mathrm{v}} 11.1$ & hERG1 & $\mathrm{KCNH} 2$ & $\begin{array}{l}\text { KCNH2 gene overexpression (Fukushiro-Lopes et al., 2017), correlation with molecular } \\
\text { subtype, grading, ER, ki67 (lorio et al., 2018), relapse (Breuer et al., 2019) }\end{array}$ \\
\hline Inward Rectifier & KCNJ3 & Kir3.1 & GIRK1, KGA & KCNJ3 & $\begin{array}{l}\text { Lymph node metastases, association with ER, independent prognostic factor (OS and DFS) } \\
\text { (Kammerer et al., 2016) }\end{array}$ \\
\hline \multirow[t]{5}{*}{$\begin{array}{l}\text { Two-pore } \\
\text { domain }\end{array}$} & KCNK5 & K2p5.1 & $\begin{array}{l}\text { TASK-2, TASK2, } \\
\text { KCNK5b }\end{array}$ & KCNK5 & Overexpression (Dookeran et al., 2017) \\
\hline & KCNK6 & K2p6.1 & $\begin{array}{l}\text { KCNK8, TOSS, } \\
\text { TWIK-2, TWIK2 }\end{array}$ & KCNK6 & Downexpression (Dookeran et al., 2017) \\
\hline & KCNK9 & K2p9.1 & $\begin{array}{l}\text { KT3.2, TASK-3, } \\
\text { TASK3 }\end{array}$ & KCNK9 & Gene amplification (Mu et al., 2003; Lee et al., 2012), Overexpression (Dookeran et al., 2017) \\
\hline & KCNK12 & K2p12.1 & THIK-2, THIK2 & KCNK12 & Overexpression (Dookeran et al., 2017) \\
\hline & KCNK15 & K2p15.1 & $\begin{array}{l}\text { KCNK11, } \\
\text { KCNK14, KT3.3, } \\
\text { TASK-5, TASK5, } \\
\text { dJ781B1.1 }\end{array}$ & KCNK15 & Downexpression (Dookeran et al., 2017) \\
\hline \multirow[t]{2}{*}{$\begin{array}{l}\text { Calcium- } \\
\text { activated }\end{array}$} & KCNMA1 & KCa1.1 & mSLO1 & KCNMA1 & $\begin{array}{l}\text { High stage, high grade, proliferation, poor prognosis (Oeggerli et al., 2012), brain metastases } \\
\text { (Khaitan et al., 2009) }\end{array}$ \\
\hline & KCNN4 & KCa3.1 & $\begin{array}{l}\text { hSK4, hKCa4, } \\
\text { hlKCa1 }\end{array}$ & KCNN4 & $\begin{array}{l}\text { High grade with negative lymph nodes (Haren et al., 2010); poor prognosis (Faouzi et al., } \\
\text { 2016) }\end{array}$ \\
\hline
\end{tabular}


et al., 2015b) and also in BC (Fukushiro-Lopes et al., 2017; Iorio et al., 2018). Through the analysis of public datasets, it was demonstrated that $\mathrm{KCNH} 2$ gene is overexpressed in $\mathrm{BC}$ (Fukushiro-Lopes et al., 2017). We recently showed that Kv11.1 protein expression in primary BCs is associated with molecular subtype (Iorio et al., 2018). In particular, we showed that Kv11.1 scoring was higher in Luminal A (tumors expressing ER, PgR, negative for HER2 expression, with a low proliferation index evaluated through Ki67 expression), progressively decreasing in Luminal B (tumors expressing ER, PgR, positive, or negative for HER2 expression, with a high proliferation index), HER2+ (tumors with high HER2 expression, low or absent ER and PgR and low Ki67) and TNBC tumors (Iorio et al., 2018). Moreover, considering all the molecular subtypes it emerged that patients with high Kv11.1 protein expression have a longer Progression-Free Survival and the same trend was observed for Local Relapse Free-Survival and Metastases-Free Survival (Iorio et al., 2018). A recent meta-analysis focused on $\mathrm{KCNH} 2$ gene expression confirmed our data, showing that high expression of the gene was associated with longer relapse-free survival (Breuer et al., 2019) and more interestingly, the association was restricted to ER-negative patients.

The inward rectifier Kir3.1 (also named KCNJ3) encoded by KCNJ3 gene, is positively associated with the development of nodal metastases (Stringer et al., 2001). The same channel was proven to be associated with ER expression and its expression was demonstrated to be an independent indicator of poor prognosis in ER-expressing tumors (Kammerer et al., 2016).

Several channels belonging to the two-pore subfamily have been shown to be aberrantly expressed in BCs. The KCNK9 gene encoding for $\mathrm{K}_{2 \mathrm{P}} 9.1$ (also indicated as KCNK9 or TASK3), has been shown to be amplified in $\mathrm{BC}$ and the corresponding channel is overexpressed ( $\mathrm{Mu}$ et al., 2003; Lee et al., 2012). Moreover, KCNK9 mediates cell migration in BC cell lines (Lee et al., 2012).

More recently, a comprehensive analysis was performed in TNBC databases of the TCGA (Dookeran et al., 2017): from such analysis it was demonstrated that in TNBC molecular subtype $K C N K 5, K C N K 9$, and $K C N K 12$ are overexpressed while KCNK6 and $\mathrm{KCNK} 15$ are down-expressed. Moreover, alterations in $\mathrm{CpG}$ island methylation were significantly associated with TNBC subtype (Dookeran et al., 2017).

In primary $\mathrm{BCs}$ the expression of $\mathrm{KCa} 1.1$ (also named $\mathrm{BK}$ ), a member of Calcium-activated subfamily encoded by KCNMA1 gene, is associated with ER expression (Oeggerli et al., 2012), the development of metastases in the brain (Khaitan et al., 2009), nuclear grade, proliferation, stage and poor prognosis (Khaitan et al., 2009). KCa1.1 was found to be expressed in different BC subtypes and is blocked by Penitrem1 (Goda et al., 2018). The expression of another member of the same family, KCa3.1 (also named KCNN4 and encoded by the KCNN4 gene) was found to be associated with high grade BCs without lymph nodes involvement (Haren et al., 2010). Another report through the analysis of public datasets highlighted the relevance of KCa3.1 in
BC since it was shown that the mRNA levels were associated with poor prognosis (Faouzi et al., 2016).

\section{POTASSIUM CHANNELS AS THERAPEUTIC TARGETS}

Several evidences have been gathered addressing the possibility of using ion channels (and in particular potassium channels) as therapeutic targets (reviewed in Arcangeli et al., 2009). A paper published in 2003 (Abdul et al., 2003) and focused on Kv1.3 channels, demonstrated that potassium channel blockers such as dequalinium and amiodarone significantly reduced MCF-7 BC cells proliferation and increased the growth-inhibitory effects of the anti-estrogen drug tamoxifen on $\mathrm{BC}$ cell lines, also those derived from TNBC (MDA-MB231) (Abdul et al., 2003).

In another interesting paper it was shown that Penitrem 1 is capable of blocking BK channels and that Penitrem $\mathrm{A}$ has a synergistic antiproliferative effect with HER-targeting drugs (Goda et al., 2018).

A member of the Calcium-activated subfamily, KCa3.1, was found to promote the acquisition of radioresistance in $\mathrm{BC}$ cells (Mohr et al., 2019), therefore it was suggested that targeting the channel during radiation therapy could result in radiosensitization of the tumor.

In vivo, it was shown that the Kv10.1 blocker astemizole impaired MBCDF and T-47D cells xenografts growth (GarcíaQuiroz et al., 2019a). Moreover, the combined treatment with astemizole and calcitriol caused a significant reduction of the T47D xenografts tumor masses as it happened in mouse models obtained inoculating primary BCs (García-Quiroz et al., 2014). The molecular bases of such effect were explained in a previous paper of the same group (García-Quiroz et al., 2012): calcitriol has an antiproliferative effect since it inhibits Kv10.1 (that modulates cell cycle and tumor progression) while astemizole is a blocker of Kv10.1 currents; the synergistic effects involve the downregulation of Cytochrome P 24A1 (CYP24A1), upregulation of Vitamin D Receptor (VDR) and Kv10.1 targeting. It was also demonstrated that Chloroquine (a drug used for the treatment of malaria that has been investigated also for its antitumoral effects) inhibited Kv10.1 currents and reduced cell migration in MDA-MB-231 cells (Valdés-Abadía et al., 2019).

Kv11.1 was proven to be a potential therapeutic target in several human solid cancers (Crociani et al., 2013; Crociani et al., 2014; Lastraioli et al., 2015c; Iorio et al., 2020). Long ago, it was demonstrated that Kv11.1 current was inhibited by tamoxifen (Thomas et al., 2003) and more recently it was shown that such inhibition is actually due to the active metabolite of tamoxifen, named endoxifen (Chae et al., 2015).

In a paper published in 2011 it was shown that Arsenic trioxide (a drug used to treat mainly promyelocitic leukemias but also effective on solid tumors) induced apoptosis of MCF-7 BC cells, through Kv11.1 inhibition (Wang et al., 2011). Another paper from the same group confirmed such evidences in vivo, in MCF-7 xenografts and also determined that the mechanism 
underlying tumor growth inhibition was centered on a Kv11.1mir328 pathway (Wang et al., 2015). Recently it was shown that small molecule activators of the Kv11.1 channel impair tumor growth and metastasis in xenografts of TNBC (Breuer et al., 2019).

More interestingly, the combination of specific channel blockers along with drugs already in use in the clinical settings (such as bevacizumab) was proven to be extremely effective since it was able to significantly reduce in vivo tumor growth in mouse models (Crociani et al., 2014). In a recent paper (Iorio et al., 2020), we demonstrated that Kv11.1 (along with HIF2 $\alpha$ ) has a positive impact on PFS of patients affected by metastatic colorectal cancer and treated with bevacizumab and could therefore be used to identify patients likely to benefit from the treatment. This finding could be of particular interest also in $\mathrm{BC}$ treatment, since the approval to use bevacizumab for metastatic $\mathrm{BC}$ patients was revoked by the FDA in 2011 due to the little improvement in favorable outcome considered not sufficient. Nevertheless, a meta-analysis of randomized controlled trials showed that the combination of chemotherapy and bevacizumab significantly improved PFS of metastatic BC patients and could therefore be used, once selected the optimal target population (Li et al., 2015).

In a different setting (pancreatic ductal adenocarcinoma), we found an association and a physical interaction between Kv11.1

\section{REFERENCES}

Abdul, M., Santo, A., and Hoosein, N. (2003). Activity of potassium channelblockers in breast cancer. Anticancer Res. 23, 3347-3351.

American Cancer Society (2017). Breast Cancer Facts \& Figures 2017-2018 (Atlanta: American Cancer Society, Inc.).

Arcangeli, A., Crociani, O., Lastraioli, E., Masi, A., Pillozzi, S., and Becchetti, A. (2009). Targeting ion channels in cancer: a novel frontier in antineoplastic therapy. Curr. Med. Chem. 16 (1), 66-93. doi: 10.2174/092986709787002835

Bauer, K., Brown, M., Cress, R. D., Parise, C. A., and Caggiano, V. (2007). Descriptive analysis of estrogen receptor (ER)-negative, progesterone receptor (PR)-negative, and HER2-negative invasive breast cancer, the so-called triplenegative phenotype: A population based study from the California Cancer Registry. Cancer. 109, 1721-1728. doi: 10.1002/cncr.22618

Bertucci, F., Finetti, P., Cervera, N., Charafe-Jauffret, E., Mamessier, E., Adélaïde, J., et al. (2006). Gene expression profiling shows medullary breast cancer is a subgroup of basal breast cancers. Cancer Res. 66, 4636-4644. doi: 10.1158/ 0008-5472.CAN-06-0031

Bijlenga, P., Occhiodoro, T., Liu, J. H., Bader, C. R., Bernheim, L., and FischerLougheed, J. (1998). An ether -à-go-go K+current, Ih-eag, contributes to the hyperpolarization of human fusion-competent myoblasts. J. Physiol. 512, 317323. doi: 10.1111/j.1469-7793.1998.317be.x

Blows, F. M., Driver, K. E., Schmidt, M. K., Broeks, A., van Leeuwen, F. E., Wesseling, J., et al. (2010). Subtyping of breast cancer by immunohistochemistry to investigate a relationship between subtype and short and long term survival: a collaborative analysis of data for 10,159 cases from 12 studies. PloS Med. 7, e1000279. doi: 10.1371/journal.pmed.1000279

Breuer, E. K., Fukushiro-Lopes, D., Dalheim, A., Burnette, M., Zartman, J., Kaja, S., et al. (2019). Potassium channel activity controls breast cancer metastasis by affecting $\beta$-catenin signaling. Cell Death Dis. 10, 180. doi: 10.1038/s41419-019$1429-0$

Brevet, M., Haren, N., Sevestre, H., Merviel, P., and Ouadid-Ahidouch, H. (2009). DNA Methylation of Kv1.3 Potassium Channel Gene Promoter is Associated and EGFR, raising the possibility of designing combined treatment schedules, also involving Kv11.1 blockers (Lastraioli et al., 2015c). Also in this case, such therapeutic approach could be applied to BC patients.

\section{CONCLUSIONS}

TNBC is characterized by a poorer prognosis with respect to other BC subtypes. Due to the absence of molecular markers there is currently no targeted therapy and the gold standard of therapy for TNBC is represented by chemotherapy. For these reasons, searching for novel biomarkers and targets for TNBC is mandatory. In this scenario, ion channels have a great potential of representing potential biomarkers due to their localization that allows an easy detection for diagnostic and prognostic purposes and could also be easily blocked by specific drugs and antibodies.

\section{AUTHOR CONTRIBUTIONS}

EL contributed solely to the article. with Poorly Differentiated Breast Adenocarcinoma. Cell. Physiol. Biochem. 24, 25-32. doi: 10.1159/000227810

Broeks, A., Schmidt, M. K., Sherman, M. E., Couch, F. J., Hopper, J. L., Dite, G. S., et al. (2011). Low penetrance breast cancer susceptibility loci are associated with specific breast tumor subtypes: findings from the Breast Cancer Association Consortium. Hum. Mol. Genet. 20, 3289-3303. doi: 10.1093/ $\mathrm{hmg} / \mathrm{ddr} 228$

Cahalan, M., and Chandy, K. (2009). The functional network of ion channels in T lymphocytes. Immunol. Rev. 231, 59-87. doi: 10.1111/j.1600-065X.2009.00816.x

Carey, L. A., Perou, C. M., Livasy, C. A., Dressler, L. G., Cowan, D., Conway, K., et al. (2006). Race, breast cancer subtypes, and survival in the Carolina Breast Cancer Study. JAMA. 295, 2492-2502. doi: 10.1001/jama.295.21.2492

Chae, Y. J., Lee, K. J., Lee, H. J., Sung, K. W., Choi, J. S., Lee, E. H., et al. (2015). Endoxifen, the active metabolite of tamoxifen, inhibits cloned hERG potassium channels. Eur. J. Pharmacol. 752, 1-7. doi: 10.1016/j.ejphar.2015.01.048

Cleator, S., Heller, W., and Coombes, R. C. (2007). Triple-negative breast cancer: Therapeutic options. Lancet Oncol. 8, 235-244. doi: 10.1016/S1470-2045(07) 70074-8

Crociani, O., Zanieri, F., Pillozzi, S., Lastraioli, E., Stefanini, M., Fiore, A., et al. (2013). hERG1 channels modulate integrin signaling to trigger angiogenesis and tumor progression in colorectal cancer. Sci. Rep. 3, 3308. doi: 10.1038/ srep03308

Crociani, O., Lastraioli, E., Boni, L., Pillozzi, S., Romoli, M. R., D'Amico, M., et al. (2014). hERG1 channels regulate VEGF-A secretion in human gastric cancer: clinicopathological correlations and therapeutical implications. Clin. Cancer Res. 20, 1502-1512. doi: 10.1158/1078-0432.CCR-13-2633

Curtis, C., Shah, S. P., Chin, S. F., Turashvili, G., Rueda, O. M., Dunning, M. J., et al. (2012). The genomic and transcriptomic architecture of 2,000 breast tumours reveals novel subgroups. Nature. 486, 346e352. doi: 10.1038/ nature 10983

D'Amico, M., Gasparoli, L., and Arcangeli, A. (2013). Potassium channels: novel emerging biomarkers and targets for therapy in cancer. Recent Pat. Anticancer Drug Discovery 8, 53-65. doi: 10.2174/1574892811308010053 
Dent, R., Trudeau, M., Pritchard, K. I., Hanna, W. M., Kahn, H. K., Sawka, C. A., et al. (2007). Triple-negative breast cancer: clinical features and patterns of recurrence. Clin. Cancer Res. 13, 4429e4434. doi: 10.1158/1078-0432.CCR-06-3045

Dookeran, K. A., Zhang, W., Stayner, L., and Argos, M. (2017). Associations of two-pore domain potassium channels and triple negative breast cancer subtype in The Cancer Genome Atlas: systematic evaluation of gene expression and methylation. BMC Res. Notes. 10, 475. doi: 10.1186/s13104-017-2777-4

Eggersmann, T. K., Degenhardt, T., Gluz, O., Wuerstlein, R., and Harbeck, N. (2019). CDK4/6 inhibitors expand the therapeutic options in breast cancer: Palbociclib Ribociclib and Abemaciclib. BioDrugs 33 (2), 125-135. doi: 10.1007/s40259-019-00337-6

Engebraaten, O., Vollan, H. K. M., and Børresen-Dale, A. L. (2013). Triplenegative breast cancer and the need for new therapeutic targets. Am. J. Pathol. 183, 1064-1074. doi: 10.1016/j.ajpath.2013.05.033

Faouzi, M., Hague, F., Geerts, D., Ay, A. S., Potier-Cartereau, M., Ahidouch, A., et al. (2016). Functional cooperation between KCa3.1 and TRPC1 channels in human breast cancer: Role in cell proliferation and patient prognosis. Oncotarget. 7 (24), 36419-36435. doi: 10.18632/oncotarget.9261

Fukushiro-Lopes, D. F., Hegel, A. D., Rao, V., Wyatt, D., Baker, A., Breuer, E. K., et al. (2017). Preclinical study of a Kv11.1 potassium channel activator as antineoplastic approach for breast cancer. Oncotarget. 9, 3321-3337. doi: 10.18632/oncotarget.22925

Fulford, L., Easton, D. F., Reis-Filho, J. S., Sofronis, A., Gillett, C. E., Lakhani, S. R., et al. (2006). Specific morphological features predictive for the basal phenotype in grade 3 invasive ductal carcinoma of breast. Histopathology. 49, 22-34. doi: 10.1111/j.1365-2559.2006.02453.x

García-Becerra, R., Díaz, L., Camacho, J., Barrera, D., Ordaz-Rosado, D., Morales, A., et al. (2010). Calcitriol inhibits Ether-à go-go potassium channel expression and cell proliferation in human breast cancer cells. Exp. Cell Res. 316, 433-442. doi: 10.1016/j.yexcr.2009.11.008

García-Quiroz, J., García-Becerra, R., Barrera, D., Santos, N., Avila, E., Ordaz-Rosado, D., et al. (2012). Astemizole synergizes calcitriol antiproliferative activity by inhibiting CYP24A1 and upregulating VDR: a novel approach for breast cancer therapy. PloS One 7 (9), e45063. doi: 10.1371/journal.pone.0045063

García-Quiroz, J., García-Becerra, R., Santos-Martínez, N., Barrera, D., OrdazRosado, D., Avila, E., et al. (2014). In vivo dual targeting of the oncogenic Ether-à-go-go-1 potassium channel by calcitriol and astemizole results in enhanced antineoplastic effects in breast tumors. BMC Cancer. 14, 745. doi: 10.1186/1471-2407-14-745

García-Quiroz, J., García-Becerra, R., Santos-Cuevas, C., Ramírez-Nava, G. J., Morales-Guadarrama, G., Cárdenas-Ochoa, N., et al. (2019a). Synergistic Antitumorigenic Activity of Calcitriol with Curcumin or Resveratrol is Mediated by Angiogenesis Inhibition in Triple Negative Breast Cancer Xenografts. Cancers (Basel). 201911 (11), E1739. doi: 10.3390/cancers11111739

García-Quiroz, J., González-González, M. E., Díaz, L., Ordaz-Rosado, D., SegoviaMendoza, M., Prado-García, H., et al. (2019b). Astemizole, an inhibitor of ether-à-go-go-1 potassium cannel, increases the activity of the tyrosine kinase inhibitor gefitinib in breast cancer cells. Rev. Invest. Clin. 71, 186-194. doi: 10.24875/RIC.18002840

Goda, A. A., Siddique, A. B., Mohyeldin, M., Ayoub, N. M., and El Sayed, K. A. (2018). The Maxi-K (BK) Channel Antagonist Penitrem A as a Novel Breast Cancer-Targeted Therapeutic. Mar Drugs 16 (5), E157. doi: 10.3390/ md16050157

Haren, N., Khorsi, H., Faouzi, M., Ahidouch, A., Sevestre, H., and OuadidAhidouch, H. (2010). Intermediate conductance Ca2+ activated $\mathrm{K}+$ channels are expressed and functional in breast adenocarcinomas: correlation with tumour grade and metastasis status. Histol. 25, 1247-1255. doi: 10.14670/ HH-25.1247

Hemmerlein, B., Weseloh, R. M., Mello de Queiroz, F., Knötgen, H., Sánchez, A., Rubio, M. E., et al. (2006). Overexpression of Eag1 potassium channels in clinical tumours. Mol. Cancer 5;41.

Iorio, J., Meattini, I., Bianchi, S., Bernini, M., Maragna, V., Dominici, L., et al. (2018). hERG1 channel expression associates with molecular subtypes and prognosis in breast cancer. Cancer Cell Int. 18, 93. doi: 10.1186/s12935-0180592-1

Iorio, J., Lastraioli, E., Tofani, L., Petroni, G., Antonuzzo, L., Messerini, L., et al. (2020). hERG1 and HIF-2 $\alpha$ Behave as Biomarkers of Positive Response to
Bevacizumab in Metastatic Colorectal Cancer Patients. Transl. Oncol. 13 (3), 100740. doi: 10.1016/j.tranon.2020.01.001

Jacquemier, J., Padovani, L., Rabayrol, L., Lakhani, S. R., Penault-Llorca, F., Denoux, Y., et al. (2005). Typical medullary breast carcinomas have a basal/ myoepithelial phenotype. J. Pathol. 207, 260-268. doi: 10.1002/path.1845

Jang, S., Kang, K. S., Ryu, P. D., and Lee, S. Y. (2009). Kv1.3 voltage-gated K(+) channel subunit as a potential diagnostic marker and therapeutic target for breast cancer. BMB. Rep. 42, 535-539. doi: 10.5483/BMBRep.2009. 42.8.535

Kammerer, S., Sokolowski, A., Hackl, H., Platzer, D., Jahn, S. W., El-Heliebi, A., et al. (2016). KCNJ3 is a new independent prognostic marker for estrogen receptor positive breast cancer patients. Oncotarget 7, 84705-84717. doi: 10.18632/oncotarget.13224

Kaplan, H. G., Malmgren, J. A., and Atwood, M. (2009). T1N0 triple negative breast cancer: Risk of recurrence and adjuvant chemotherapy. Breast J. 15, 454-460. doi: 10.1111/j.1524-4741.2009.00789.x

Khaitan, D., Sankpal, U. T., Weksler, B., Meister, E. A., Romero, I. A., Couraud, P. O., et al. (2009). Role of KCNMAl gene in breast cancer invasion and metastasis to brain. BMC Cancer 9, 258. doi: 10.1186/1471-2407-9-258

Kreike, B., van Kouwenhove, M., Horlings, H., Weigelt, B., Peterse, H., Bartelink, H., et al. (2007). Gene expression profiling and histopathological characterization of triple-negative/basal-like breast carcinomas. Breast Cancer Res. 9, R65. doi: 10.1186/bcr1771

Lastraioli, E., Iorio, J., and Arcangeli, A. (2015a). Ion channel expression as promising cancer biomarker. Biochim. Biophys. Acta 1848 (10 Pt B), 26852702. doi: 10.1016/j.bbamem.2014.12.016

Lastraioli, E., Lottini, T., Bencini, L., Bernini, M., and Arcangeli, A. (2015b). hERG1 Potassium Channels: Novel Biomarkers in Human Solid Cancers. BioMed. Res. Int. 2015, 896432. doi: 10.1155/2015/896432

Lastraioli, E., Perrone, G., Sette, A., Fiore, A., Crociani, O., Manoli, S., et al. (2015c). hERG1 channels drive tumour malignancy and may serve as prognostic factor in pancreatic ductal adenocarcinoma. Br. J. Cancer. 112 (6), 1076-1087. doi: 10.1038/bjc.2015.28

Lastraioli, E. (2018). Potassium channels in breast cancer. Ann. Breast Cancer. 2, 1006.

Lee, G. W., Park, H. S., Kim, E. J., Cho, Y. W., Kim, G. T., Mun, Y. J., et al. (2012). Reduction of breast cancer cell migration via up-regulation of TASK-3 twopore domain K+ channel. Acta Physiol. (Oxf). 204, 513-524. doi: 10.1111/ j.1748-1716.2011.02359.x

Li, Q., Yan, H., Zhao, P., Yang, Y., and Cao, B. (2015). Efficacy and Safety of Bevacizumab Combined with Chemotherapy for Managing Metastatic Breast Cancer: A Meta-Analysis of Randomized Controlled Trials. Sci. Rep. 5, 15746. doi: 10.1038/srep15746

Liu, G. X., Yu, Y. C., He, X. P., Ren, S. N., Fang, X. D., Liu, F., et al. (2015). Expression of eag1 channel associated with the aggressive clinicopathological features and subtype of breast cancer. Int. J. Clin. Exp. Pathol. 8, 15093-15099.

Livasy, C. A., Karaca, G., Nanda, R., Tretiakova, M. S., Olopade, O. I., Moore, D. T., et al. (2006). Phenotypic evaluation of the basal-like subtype of invasive breast carcinoma. Mod. Pathol. 19, 264-271. doi: 10.1038/modpathol.3800528

McCann, K. E., and Hurvitz, S. A. (2018). Advances in the use of PARP inhibitor therapy for breast cancer. Drugs Context 7, 212540. doi: 10.7573/dic. 212540

Millikan, R. C., Newman, B., Tse, C. K., Moorman, P. G., Conway, K., Dressler, L. G., et al. (2008). Epidemiology of basal-like breast cancer. Breast Cancer Res. Treat 109, 123-139. doi: 10.1007/s10549-007-9632-6

Mohr, C. J., Gross, D., Sezgin, E. C., Steudel, F. A., Ruth, P., Huber, S. M., et al. (2019). $\mathrm{K}_{\mathrm{Ca}} 3.1$ Channels Confer Radioresistance to Breast Cancer Cells. Cancers (Basel) 11 (9), E1285. doi: 10.3390/cancers11091285

Mu, D., Chen, L., Zhang, X., See, L. H., Koch, C. M., Yen, C., et al. (2003). Genomic amplification and oncogenic properties of the KCNK9 potassium channel gene. Cancer Cell. 2003, 3, 297-302. doi: 10.1016/S1535-6108(03)00054-0

Nielsen, T. O., Hsu, F. D., Jensen, K., Cheang, M., Karaca, G., Hu, Z., et al. (2004). Immunohistochemical and clinical characterization of the basal-like subtype of invasive breast carcinoma. Clin. Cancer Res. 10, 5367e5374. doi: 10.1158/10780432.CCR-04-0220

Oeggerli, M., Tian, Y., Ruiz, C., Wijker, B., Sauter, G., Obermann, E., et al. (2012). Role of KCNMA1 in breast cancer. PloS One 7, e41664. doi: 10.1371/ journal.pone.0041664 
Ouadid-Ahidouch, H., Ahidouch, A., and Pardo, L. A. (2016). Kv10.1 K ${ }^{+}$channel: from physiology to cancer. Pflugers Arch. - Eur. J. Physiol. 468, 751-762. doi: 10.1007/s00424-015-1784-3

Penault-Llorca, P., and Viale, G. (2012). Pathological and molecular diagnosis of triple-negative breast cancer: a clinical perspective. Ann. Oncol. 23 (Suppl. 6), vi19-vi22. doi: 10.1093/annonc/mds190

Perou, C. M., and Børresen-Dale, A. L. (2011). Systems biology and genomics of breast cancer. Cold Spring Harb. Perspect. Biol. 3, a003293. doi: 10.1101/ cshperspect.a003293

Reis-Filho, J. S., Milanezi, F., Steele, D., Savage, K., Simpson, P. T., Nesland, J. M., et al. (2006). Metaplastic breast carcinomas are basal-like tumours. Histopathology. 49, 10-21. doi: 10.1111/j.1365-2559.2006.02467.x

Rodriguez-Pinilla, S. M., Rodríguez-Gil, Y., Moreno-Bueno, G., Sarrió, D., MartínGuijarro M del, C., Hernandez, L., et al. (2007). Sporadic invasive breast carcinomas with medullary features display a basal-like phenotype: An immunohistochemical and gene amplification study. Am. J. Surg. Pathol. 31, 501-508. doi: 10.1097/01.pas.0000213427.84245.92

Santana-Davila, R., and Perez, E. A. (2010). Treatment options for patients with triple negative breast cancer. J. Hematol. Oncol. 3, 42. doi: 10.1186/1756-8722-3-42

Sasa, M., Bando, Y., Takahashi, M., Hirose, T., and Nagao, T. (2008). Screening for basal marker expression is necessary for decision of therapeutic strategy for triple- negative breast cancer. J. Surg. Oncol. 97, 30-34. doi: 10.1002/jso.20906

Stringer, B. K., Cooper, A. G., and Shepard, S. B. (2001). Overexpression of the Gprotein inwardly rectifying potassium channel 1 (GIRK1) in primary breast carcinomas correlates with axillary lymph node metastasis. Cancer Res. 61, 582-588.

Teisseyre, A., Gąsiorowska, J., and Michalak, K. (2015). Voltage-Gated Potassium Channels Kv1.3-Potentially New Molecular Target in Cancer Diagnostics and Therapy. Adv. Clin. Exp. Med. 24, 517-524. doi: 10.17219/acem/22339

Teisseyre, A., Palko-Labuz, A., Sroda-Pomianek, K., and Michalak, K. (2019). Voltage-Gated Potassium Channel Kv1.3 as a Target in Therapy of Cancer. Front. Oncol. 9, 933. doi: 10.3389/fonc.2019.00933
Thomas, D., Gut, B., Karsai, S., Wimmer, A. B., Wu, K., Wendt-Nordahl, G., et al (2003). Inhibition of cloned HERG potassium channels by the antiestrogen tamoxifen. Naunyn Schmiedebergs Arch. Pharmacol. 368 (1), 41-48. doi: 10.1007/s00210-003-0766-8

Tot, T. (2000). The cytokeratin profile of medullary carcinoma of the breast. Histopathology. 37, 175-181. doi: 10.1046/j.1365-2559.2000.00889.x

Valdés-Abadía, B., Morán-Zendejas, R., Rangel-Flores, J. M., and RodríguezMenchaca, A. A. (2019). Chloroquine inhibits tumor-related Kv10.1 channel and decreases migration of MDA-MB-231 breast cancer cells in vitro. Eur. J. Pharmacol. 855, 262-266. doi: 10.1016/j.ejphar.2019.05.017

Wang, Y., Zhang, Y., Yang, L., Cai, B., Li, J., Zhou, Y., et al. (2011). Arsenic trioxide induces the apoptosis of human breast cancer MCF-7 cells through activation of caspase-3 and inhibition of HERG channels. Exp. Ther. Med. 2, 481-486. doi: 10.3892/etm.2011.224

Wang, Y., Wang, L., Yin, C., An, B., Hao, Y., Wei, T., et al. (2015). Arsenic trioxide inhibits breast cancer cell growth via microRNA-328/hERG pathway in MCF-7 cells. Mol. Med. Rep. 12(1), 1233-1238. doi: 10.3892/mmr.2015.3558

Yu, K., Rohr, J., Liu, Y., Li, M., Xu, J., Wang, K., et al. (2020). Progress in triple negative breast carcinoma pathophysiology: Potential therapeutic targets. Pathol. Res. Pract. 216, 152874. doi: 10.1016/j.prp.2020.152874

Conflict of Interest: The author declares that the research was conducted in the absence of any commercial or financial relationships that could be construed as a potential conflict of interest.

Copyright (c) 2020 Lastraioli. This is an open-access article distributed under the terms of the Creative Commons Attribution License (CC BY). The use, distribution or reproduction in other forums is permitted, provided the original author(s) and the copyright owner(s) are credited and that the original publication in this journal is cited, in accordance with accepted academic practice. No use, distribution or reproduction is permitted which does not comply with these terms. 